\title{
From Homo Oeconomicus to Homo Praeventicus
}

\author{
Julia M. Puaschunder ${ }^{1,2}$ \\ ${ }^{1}$ The New School, Parsons School of Design, Department of Economics, 6 East $16^{\text {th }}$ Street, $9^{\text {rd }}$ floor 89, New York, \\ NY 10003,USA, Julia.Puaschunder@newschool.edu, T 001212229 5700,F 0012122295724. \\ www.juliampuaschunder.com \\ ${ }^{2}$ Columbia University, Graduate School of Arts and Sciences, Julia.Puaschunder@columbia.edu, \\ http://blogs.cuit.columbia.edu/jmp2265
}

\begin{abstract}
Standard economic models primarily captured human beings to be rational utility maximizers in the homo oeconomicus model. Behavioral economics addressed human decision making fallibility in a wide range of studies including laboratory and field experiments as well as big data. The currently ongoing COVID-19 crisis now underlines the importance of a healthy work environment. The medicine of the future is believed to prevent diseases instead of just treating their consequences. There is an expected shift from modern medicine's focus on acute treatment to address the inherently-underlying preventive measures that diseases would have a more favorable trajectory or are even avoidable at all. The homo praeventicus model may focus on preventing diseases and working in advance on favorable immune conditions that avert negative outbreaks of pandemics or determine a healthier state when falling sick. The homo oeconomicus offers as a remedy to chronic diseases and a reduction of a global cost escalation for medical care. Because we have to live with environmental burdens on our health, a change of direction towards prevention is recommended and the implementation of homo praeventicus models envisioned.
\end{abstract}

KEYWORDS: AI, Artificial Intelligence, Coronavirus, COVID-19, Discounting, Healthcare, Homo oeconomicus, Homo praeventicus, Medical care, Precautionary principle, Prevention, Trajectory

\section{Introduction}

The most recent decade featured a data revolution in the healthcare sector in screening, monitoring and coordination of aid (Puaschunder 2019b). Big data analytics have revolutionized the medical profession (Puaschunder 2019f). The health sector relies on Artificial Intelligence (AI) and robotics as never before (Puaschunder 2019c). The opportunities of unprecedented access to healthcare, rational precision and human resemblance but also targeted aid in decentralized aid grids are obvious innovations that will lead to most sophisticated neutral healthcare in the future (Puaschunder 2019f). Together with big data driven medical insights, preventive medicine has leveraged into unprecedented opportunities, precision and sophistication (Puaschunder forthcoming b).

Preventive medicine integrates the big picture by including the genetic predispositions, history, chronology and environmental influences (Salzburg Declaration 2020). Preventive medical care thereby tries to evade diseases and cure chronic diseases in the context of a systems biology perspective (Salzburg Declaration 2020). Preventive medicine is based on a precautious principle to promote healthy lifestyle rather than curing with traditional healing methods afterwards (Ecowellness 2020). Preventive medicine includes multi-faceted benefits of psychosomatic medicine and leaves aside short-term or unbalanced profit-maximization calculations of ordinary emergency healthcare (Ecowellness 2020; Salzburg Declaration 2020).

\section{COVID-19}

In the novel Coronavirus crisis, prevention and general, holistic medicine determine whether COVID19 puts patients on a severe or just mild symptom trajectory (CDC Center for Disease Control and 
Prevention 2020). Obesity, but also the general status of the immune system are decisive in whether the Coronavirus becomes a danger for the individual (Ecowellness 2020; Salzburg Declaration 2020). The COVID-19 crisis is therefore an important accelerator for necessary, fundamental changes in the health system, which also results in economic, philosophical and ethical demands on politics. Every year, millions of people die of viruses, cancer, diabetes, Alzheimer's, dementia, pathological obesity and mental illnesses and this number is increasing worldwide (Sachs et al. 2020). Obesity is already classified as a pandemic by the WHO and has been recognized as one of the causes of reduced immunity and recently also as a risk factor for COVID-19 diseases. Prevention is currently given top priority in the population planning and financed by a respectively precautionary healthcare system. The self-monitoring of the state of health and the comprehensive prevention in a holistic lifestyle according to the German Prevention Act of 2015 of the German Federal Government are today's competitive advantages in all the economies around the world that are affected by the pandemic and health crisis (Salzburg Declaration 2020).

The time is therefore ripe for focus on prevention. A shift from homo oeconomicus as the utility maximizer, which behavioral economics proved to be hindered by discounting fallibilities is therefore transitioned to a homo praeventicus model. The homo oeconomicus model attributed human beings fully capable of calculating and maximizing utility at a constant basis. Behavioral Economics revolutionized decision-making theory by showing in an impressive line of research how individuals constantly deviate from rationality. Behavioral economists have recently started to nudge - and most recently wink - people into favorable decision outcomes. With the COVID-19 pandemic underlining the importance of hygiene and preventive healthcare, the time is ripe to shift to homo praeventicus grounded on behavioral insights how to coordinate more effectively on preventive healthcare.

\section{Homo praeventicus}

Homo praeventicus addressed the novel attention to precautionary principle based medical care that focuses on prevention rather than emergency medicine. The time is now for preventive medical care due to three currently ongoing trends (1) Big data digitalization revolution and computational power hold unprecedented opportunities to reap the benefits from prevention; (2) The currently ongoing novel Coronavirus crisis accelerates the call for prevention as a lifestyle that builds a stable immune system long-term to shield from diseases outbreaks and unfavorable trajectories; (3) The ecologic crisis around climate change calls for attention to an ecologic lifestyle of which preventive medical care and a whole-roundedly ecological lifestyle can be supportive given the ecological costs of an unhealthy diet and energy consumption of emergency care.

Big data digitalization and computational power hold unprecedented scientific and financial opportunities (Puaschunder 2020c). Most innovative novel big data insights allow for crowd understanding, trends prediction and preventive healthcare control, e.g. in genetic testing such as 278 tests via blood in the US, egg freezing hand-picked most prosperous genetic material, 23andme insights (Puaschunder 2018a, 2019g).

What is new these days is the entry of artificial intelligence (AI), algorithms and large data sets into the medical field, which raise prevention to a new level. As early as November 2019, experts identified new technologies such as robots, AI, algorithms and large data-generated findings as helpful innovations in the medical sector (Puaschunder 2019e, f). Customized datadriven preventive medicine is considered to be one of the most groundbreaking achievements of today's medicine (Puaschunder 2019f). Efficiency, precision and better quality work are highlighted as advantages of AI, robots and big data in healthcare. Decentralized preventive medicine and telemedicine enable personalized preventive care that makes health more accessible to large parts of the population (Puaschunder 2019f). The power of big data aids our understanding 
of group behavior and trend predictions as well as preventive health care - such as through genetic predisposition and origin tests in the USA and handpicked genetic material selection. Health apps target at preventing COVID. Bluetooth-tracking of medical devices helps overcome bottlenecks and fraud while protecting privacy. Telemedicine cures remotely. Future global digi-healthcare innovations are likely to come from corruption-free AI pioneering countries that tend to have better general medical care (Puaschunder \& Beerbaum 2020). Internet connectivity and AI-humancompatibility are growing competitive advantages (Puaschunder 2020d).

Puaschunder (forthcoming b) compiled three indices in order to compare international differences in digitization, economic potential, anti-corruption and access to good public medical care. Different aspects and combinations of artificial intelligence and economic growth, freedom from corruption and public health care showed that digitized connectivity as a proxy for artificial intelligence goes hand in hand with freedom from corruption, which in turn is correlated with good medical care (Puaschunder forthcoming b). These nations and especially Europe in an international comparison have the best prerequisites for a leadership role in global pandemic containment and risk management through new technologies in medicine but also to be able to offer predictive prevention excellence to the entire world (Puaschunder forthcoming $b$ ).

In the healthcare sector, those countries hold a prevention medical care advantage that have a historically-grown wealth of data and a homogenous population. Technological innovation leaders can pick up technological advancements around the world quickly and efficiently. Precautionary standards in releasing drugs evolve in territories with relative independence of market actors - in the US, for instance, big data insights are regulated by the Federal Trade Commission (FTC) and the Federal Communications Commission (FCC), two agencies that are more market oriented. European citizens pay for free universal healthcare by automatic provision of data. In the age of information, in which big data has become the new untaxed wealth generation means, novel computational advancements can now retrieve medical insights from patient data that can be capitalized, especially for preventive medical care. Contrary to the US, within the EU healthcare is oriented towards preventive rather than emergency and reconstructive medicine and puts a human face on capitalism. The US medical market is more fractionated into public and private sector health and features a more market-focused approach, in which ethics often get sidetracked. China offers a traditionally completely different Asian medicine school and human rights standards are challenged when it comes to harvesting prisoners for organs and access to medical care becoming dependent on social credit scores. Europe can therefore offer the world a big data-driven preventive medical care in the Western tradition with particular attention to ethics (Puaschunder 2018a, 2020a, forthcoming a). All these novel opportunities and insights derived from big data, however, hold challenging ethical questions, among which privacy, stigmatization and discrimination account for the most pressing ones (Puaschunder 2017b, c, d, e).

As the novel Coronavirus has drawn attention to prevention (Piper 2020; Puaschunder 2019b). With the novel Coronavirus (COVID-19) spreading around the world from the beginning of 2020 on, calls are made that the medicine of the future should prevent diseases instead of just treating their consequences. In the novel Coronavirus crisis, prevention and general, holistic medicine determine whether COVID-19 puts patients on a severe or just mild symptom trajectory. Obesity, but also the general status of the immune system are decisive in whether the Coronavirus becomes a danger for the individual. The COVID-19 crisis is therefore an important accelerator for necessary, fundamental changes in the health system, which also results in ecological impacts as a healthy diet is usually less carbon intensive.

With the COVID-19 pandemic, the connection between preventive medicine, general health and prevalence has gained unprecedented momentum. Due to a weakened immune system being related to a severe disease trajectory, preventive medical care has become more important for emergency medicine. In the novel Coronavirus crisis, prevention and general, holistic medicine determine whether COVID-19 puts patients on a severe or just mild symptom trajectory. Obesity, but also the general status of the immune system are decisive in whether the Coronavirus becomes 
a danger for the individual. In light of the heightened health risks of COVID-19, employers will naturally select healthier workers that may have to positive externality effect of an overall more productive labor at work. Already now elder and chronic patients' passing and vulnerabilities risks change labor market demand towards favoring young, healthier and Corona-survivors, who may benefit from a natural immunity, and being more virus-resistant (Puaschunder \& Gelter 2020).

As for outside working conditions, those corporations that are placed in benevolent healthpromoting territories will have a competitive advantage and gain in terms of labor quality. Countries around the world are currently paying attention to preventive medical care in the wake of pandemic outbreak monitoring. Those nations that can offer technological advancements to monitor pandemic outbreaks but also medicine of the future that helps prevent diseases instead of just treating their consequences will produce positive labor advantages (Salzburg Declaration 2020).

Ecologic system change may occur that benefits from healthcare prevention. As a healthy diet is also ecologically friendlier in comparison to meat-based nutrition, the homo praeventicus model also takes into account the health of our planet. The modern epidemics and the climate crisis are mainly caused by human actions based on discounting fallibility. The neglect of healthcare prevention goes hand in hand with an ecologically unfavorable lifestyle of meat consumption. Instead of just curing symptoms and practicing epidemic hygiene, causal control could now stress preventive medical care based on a healthy lifestyle that is also ecologically sound (Puaschunder 2020b).

In most recent decades, affluent people in high-income countries have defined environmental conscientiousness as luxury good. High-end consumers around the world then have proven interest in goods that do not cause $\mathrm{CO}_{2}$ emissions (Puaschunder 2017a). They travel and shop environmentally-conscientious with respect for the wider community and are investing to fund social and environmental causes in their local communities. Behavioral insight - hence the behavioral economics application onto global governance - proves in many powerful laboratory and field experiments the power of behavioral nudges and winks on consumer choices with less money incentives (Puaschunder 2019d). Nudges, the behavioral means to change people's choices based on their emotions, status and other environmental and social conditions, have proven to be powerful and easily-implementable sources to educate and change people's behavior without direct enforcement (Puaschunder forthcoming a, b).

Governments may not be trapped in primarily focusing on locking-down the population as crisis management during a pandemic and leave them alone in quarantine after positive Coronavirus tests, but also take measures that can guarantee continued health and safe employment - including those of the companies (Puaschunder \& Gelter 2020). Preventive medical care could thereby become the central theme of business, ecology and politics as we redefine our society in the post-COVID-19 world. Return-on-investment and sales for GDP as a rating of success should also integrate the long-term state of the overall health of the workforce and environmental conditions of the nation. In this light, the "homo oeconomicus" is outdated by the "homo praeventicus" in all aspects the innovation-based growth as well as for ecological harmony.

\section{Discussion}

Today we witness three trends that result in a large-scale system change towards preventive self-care. Digitalization, pandemic outbreak and ecological limits instigate system change from an emergency and restorative medicine focus towards preventive medical care. While medical care was dominated by industries that aim to maximize profits in the past, the current trends of digitalization, pandemic outbreak and climate stabilization demands may steer the world towards humanity in prevention rather than profit maximization (Puaschunder 2020b). The emergency-based medical care that only cures when diseases break out thereby primarily is obsessed with symptoms but not pro-actively tackling causes, may shift towards care in advance and protection from causes, not only becoming 
acting in curing symptoms that are more lucrative. Financial beneficiaries of wrong incentivization mechanisms have led to a continuous cost increase for a healthy life in the past. The COVID-19 crisis may serve as a wake-up call for attention to promoting healthy lifestyles upfront. Leaving aside short-term or unbalanced profit maximization calculations when it comes to healthcare, we may not only tap into the incredibly new resources stemming from big data digitalization techniques, but future research may also address the best possible implementation to evaluate and integrate traditional healing methods to prevent. All these endeavors may foster a future healthy life that is balanced within the ecological limits of our all common earth.

\section{References}

Interdisciplinary Conference on 'System change?! The chance of transformation of the healthcare system: Analysis and chances of the coronavirus crisis, July 14-15, 2020, EcoWellness Group, https://www.oekowellness.de/laenderuebergreifende-konzerenz-zum-thema-system-change-diechance-der-transformation-des-gesundheitswesens-14-07-2020/ (Acessed August 12, 2020).

Piper, Nikolaus. 2020. „Die Ökonomie des Todes.“ Süddeutsche Zeitung, April 10, 2020. Retrieved at https://www.sueddeutsche.de/wirtschaft/pest-coronavirus-wirtschaft-1.4873813.

Puaschunder, Julia Margarete. 2017a. Global responsible intergenerational leadership. Wilmington, DE: Vernon.

Puaschunder, Julia Margarete. 2017b. "Nudging in the digital big data era." European Journal of Economics, Law and Politics 4(4): 18-23.

Puaschunder, Julia Margarete. 2017c. "Nudgital: Critique of a behavioral political economy." Archives of Business Research 5(9): 54-76.

Puaschunder, Julia Margarete. 2017d. "Nudgitize me! A behavioral finance approach to minimize losses and maximize profits from heuristics and biases." International Journal of Management Excellence 10(2): 1241-1256.

Puaschunder, Julia Margarete. 2017e. "The nudging divide in the digital big data era." International Journal of Research in Business, Economics and Management 4(11-12): 49-53.

Puaschunder, Julia Margarete. 2018a. "Dignity and utility of privacy and information sharing in the digital big data age." International Journal of Commerce and Management Research 5(4): 62-70.

Puaschunder, Julia Margarete. 2018b. "Towards a utility theory of privacy and information sharing and the introduction of hyper-hyperbolic discounting in the digital big data age." International Journal of Strategic Information Technology and Applications 10(1): 1-22.

Puaschunder, Julia Margarete. 2019a. "Artificial diplomacy: A guide for public officials to conduct Artificial Intelligence." Journal of Applied Research in the Digital Economy 1: 39-45.

Puaschunder, Julia Margarete. 2019b. Artificial Intelligence, big data, and algorithms in healthcare, Report on behalf of the European Parliament European Liberal Forum in cooperation with The New Austria and Liberal Forum, Retrieved at https://papers.ssrn.com/sol3/papers.cfm?abstract_id=3472885.

Puaschunder, Julia Margarete. 2019c. "Artificial Intelligence market disruption." Proceedings of the International RAIS Conference on Social Sciences and Humanities organized by Research Association for Interdisciplinary Studies at Johns Hopkins University, Montgomery County Campus, Rockville, MD, United States, June 10-11, 1-8.

Puaschunder, Julia Margarete. 2019d. Intergenerational equity: Corporate and financial leadership. Cheltenham, UK \& Northampton, MA: Edward Elgar.

Puaschunder, Julia Margarete. 2019e. "On Artificial Intelligence's razor's edge: On the future of democracy and society in the artificial age." Journal of Economics and Business 2(1): 100-119.

Puaschunder, Julia Margarete. 2019f. Stakeholder perspectives on Artificial Intelligence (AI), robotics and big data in healthcare: An empirical study, Retrieved at https://papers.ssrn.com/sol3/papers.cfm?abstract_id=3497261.

Puaschunder, Julia Margarete. 2019g. The legal and international situation of AI, robotics and big data with attention to healthcare. Reports on behalf of the European Parliament European Liberal Forum in cooperation with The New Austria and Liberal Forum, Retrieved at https://papers.ssrn.com/sol3/papers.cfm?abstract_id=3472885. 
Puaschunder, Julia Margarete. 2020a. Data fiduciary in order to alleviate principal-agent problems in the artificial big data age. 46th Eastern Economic Association Conference, Boston Sheraton, Boston, Massachusetts, United States, February 29.

Puaschunder, Julia Margarete. 2020b. Governance and Climate Justice: Global South and developing nations. Cham: Palgrave Macmillan.

Puaschunder, Julia Margarete. 2020c. On freedom in the artificial age, Retrieved at https://papers.ssrn.com/sol3/papers.cfm?abstract_id=3544348.

Puaschunder, Julia Margarete. 2020d. "Revising growth theory in the Artificial Age: Putty and clay labor." Archives in Business Research 8(3): 65-107.

Puaschunder, Julia Margarete. forthcoming a. "Big data ethics." Journal of Applied Research in the Digital Economy 1: 55-75.

Puaschunder, Julia Margarete. forthcoming b. "The future of Artificial Intelligence in international healthcare: Integrating technology, productivity, anti-corruption and healthcare interaction around the world with three indices." Journal of Applied Research in the Digital Economy.

Puaschunder, Julia Margarete \& Dirk Beerbaum. 2020. „The Future of Healthcare around the World: Four indices integrating Technology, Productivity, Anti-Corruption, Healthcare and Market Financialization." Research Association for Interdisciplinary Studies Conference Proceedings of the 18th Interdisciplinary RAIS conference at Princeton University, Princeton, New Jersey, United States, August 17-18, pp. 164-185, 2020. [Held online due to COVID-19].

Puaschunder, Julia Margarete \& Dirk Beerbaum. 2020. "Healthcare inequality in the digital $21^{\text {st }}$ century: The case for a mandate for equal access to quality medicine for all." Book of Abstracts of the Unequal World Conference, United Nations New York, New York, United States.

Puaschunder, Julia Margarete. \& Martin Gelter. forthcoming. "COVID-19 and comparative corporate governance." Journal of Corporation Law.

Sachs, Jeffrey D., Richard Horton, Jessamy Bagenal, Yanis Ben Amor, Ozge Karadag Caman \& Guillaume Lafortun. 2020. The Lancet COVID-19 Commission, The Lancet (July 9, 2020), https://www.thelancet.com/pdfs/journals/lancet/PIIS0140-6736(20)31494-X.pdf. Doi.org/10.1016/S0140-6736(20)31494-X.

Salzburg Declaration, EcoWellness Group ICQ on behalf of the World Economic Forum Reset Programme.

Symptoms of Coronavirus Disease, Coronavirus Disease 2019 (COVID-19), CDC Center for Disease Control and Prevention, https://www.cdc.gov/coronavirus/2019-ncov/symptomstesting/symptoms.html (last visited August 12, 2020).

United Nations 2020. UN Response to COVID-19. https://www.un.org/en/coronavirus/UN-response (last visited August 12, 2020). 